\author{
AGNIESZKA TAMBOR \\ (D) https://orcid.org/0000-0003-1536-8986 \\ Uniwersytet Śląski \\ Katowice
}

\title{
Film jako narzędzie pomocnicze w procesie adaptacji migrantów - imigrantów i uchodźców
}

Film as a tool to assist in the process of adaptation of migrants - immigrants and refugees

\begin{abstract}
Film is one of the media which, due to their accessibility and popularity, can be easily used in today's world as a tool supporting integration and the process of integration into a foreign culture, which is often very distant (geographically and mentally). The paper is based on the assumption that a foreign culture cannot be learned, but that one can get to know it and to learn as much as possible "about it". The aim of the text is to indicate which criteria should be taken into account when selecting films intended for immigrants and refugees, and how these films may support the process of adaptation to the Polish culture.
\end{abstract}

Key words: film, adaptation, accommodation, immigrant, refugees

„Często jako motywacja do rozpoczęcia nauki języka obcego podawana jest chęć poznania/zbadania kultury społeczności, która się nim posługuje. Język jawi się jako klucz do rozszyfrowania manuskryptu kultury, a tym samym zrozumienia »Obcego«" (Achtelik 2013, 137). Ta teza sformułowana przez Aleksandrę Achtelik wydaje się fundamentalna z punktu widzenia rozważań dotyczących adaptacji do życia w nowym kraju przez imigrantów i uchodźców. Oczywiście, owa chęć zbadania/poznania obcej kultury nie jest w tym przypadku motywacją a raczej koniecznością wynikającą ze znalezienia się w nierzadko bardzo odległej (geograficznie i/lub mentalnie) strefie kulturowej. Adaptacja, która jest procesem wielotorowym, aby była efektywna, przebiegać powinna nie tylko na gruncie językowym, ale także, a może w niektórych przypadkach: przede wszystkim, na gruncie psychologiczno- 
-kulturowym. Składające się na udaną adaptację procesy akomodacji i integracji wymagają od zainteresowanego wysiłku polegającego na próbie przystosowania się do nowego środowiska, jego obyczajów, tradycji i przyjęcia (często nawet wbrew własnym chęciom) różnego rodzaju ,zachowań kulturowych”.

Poprawne i efektywne wdrożenie migranta w ramy nowej kultury domaga się w pierwszej kolejności rozważenia zagadnienia:

Czy kultury mają narodowości? Na ile zasadne jest mówienie o polskim sposobie życia, który będąc innym od czeskiego czy niemieckiego, jest własnością jakiegoś wyraźnie wyodrębnionego podmiotu społecznego? W jakim stopniu uniwersa podzielanych znaczeń i wspólnoty komunikacyjne pokrywają się z podziałami narodowymi? Czy sposób życia »podług wartości« może mieć irlandzki, angielski czy amerykański charakter (Miodunka, Seretny 2008, 277).

Te rozważania podjęte kilka lat temu przez specjalistów-glottodydaktyków, dziś - w okresie, który określić można śmiało jako dekadę migracji - nabierają zupełnie innego charakteru. W 2019 roku, kiedy poszczególne kraje europejskie zaadaptowały (albo przynajmniej podjęły próby adaptacji) pierwsze osiadłe grupy uchodźców i imigrantów (w Europie Zachodniej i Południowej$^{1}$ byli to przede wszystkim mieszkańcy Bliskiego Wschodu i Afryki, w Polsce zaś - Ukraińcy $\left.{ }^{2}\right)^{3}$, kiedy przywódcy państw europejskich i samego Zjednoczonego Królestwa zmagają się z wielomiesięcznymi negocjacjami dotyczącymi Brexitu, czyli wyjścia Wielkiej Brytanii z Unii Europejskiej mo-

1 „Na teren państw europejskich od początku 2015 roku do końca sierpnia dotarło ponad 310 tysięcy uchodźców” (https://pl.wikipedia.org/wiki/Kryzys_migracyjny_w_Europie\# Polska [dostęp: 9.04.2019]); „,Na 4,3 mln imigrantów w 2016 r. składało się w przybliżeniu 2,0 mln obywateli państw nienależących do UE, 1,3 mln obywateli innego państwa członkowskiego UE niż to, do którego wyemigrowali, około 929 tys. osób migrujących do państwa członkowskiego UE, którego obywatelstwo już posiadali (na przykład powracający obywatele lub obywatele urodzeni za granica) oraz około 16 tys. bezpaństwowców" (https://ec.europa. eu/eurostat/statistics-explained/index.php?title=Migration_and_migrant_population_statisti cs/pl\#Przep.C5.82ywy_migracyjne:_2_mln_imigrant.C3.B3w_spoza_UE [dostęp: 11.04.2019]).

2 ,3 czerwca 2017 Rzecznik Prasowy Ministerstwa Spraw Zagranicznych na stronie internetowej umieścił oświadczenie, w którym można przeczytać, że w roku 2016 Polska przyjęła ponad milion migrantów i uchodźców z Ukrainy i zza wschodniej granicy" (https://pl.wikipe dia.org/wiki/Kryzys_migracyjny_w_Europie\#Polska [dostęp: 9.04.2019]).

${ }^{3}$ We wszystkich przypadkach na grupy te składają się zarówno uchodźcy uciekający przed działaniami wojennymi, jak i imigranci zarobkowi.

${ }^{4} \mathrm{~W}$ istocie duża część sporu dotyczy właśnie różnic kulturowych i sposobu postrzegania świata przez przedstawicieli różnych narodów należących do Wspólnoty. Drugim, ważnym 
żemy, a właściwie powinniśmy z coraz większą pewnością, wynikającą z codziennych doświadczeń i obserwacji świata dookoła, dyskutować o statusie migranta oraz o sposobach przystosowywania się poszczególnych grup ${ }^{5}$ do życia w nowych warunkach społecznych. Adaptacja do „obcego świata” jest uzależniona od kilku podstawowych czynników, wśród których są m.in.: płeć, wiek, miejsce urodzenia/wychowania oraz wyznawana religia ${ }^{6}$. Ważnym czynnikiem jest także powód zmiany miejsca zamieszkania. Inne będą motywatory, po które należy sięgnąć w pracy z imigrantem zarobkowym, inne zaś te, które zachęcą uchodźcę do pracy i poznawania nowej kultury oraz języka7.

Czy zatem obcej kultury można się nauczyć, wchłonąć ją, w pełni zinternalizować? Raczej bez wahania należałoby odpowiedzieć, że nie. Można ja jednak poznać, oswoić i nauczyć się jak najwięcej „o niej”. Przyjrzyjmy się przykładowi: oto Chińczyk mieszkający kilka lat w Polsce, w kraju ojczystym jedną z najważniejszych reguł wyznaczających rutynę dnia codziennego jest dla niego jedzenie obiadu około 12:00. Czy podczas dłuższego pobytu w Polsce możliwe jest zachowanie tego zwyczaju? Z cała pewnością nie. Po pierwsze, ani na polskich uczelniach, ani w firmach nie przewiduje się w południe przerwy na lunch ${ }^{9}$, po drugie, nie jest to godzina, o której większość Polaków miałaby ochotę na jakikolwiek posiłek. A zatem, nawet najbardziej przywiązany do swych ojczystych zwyczajów konsumpcyjnych mieszkaniec Państwa Środka będzie zmuszony zmienić przyzwyczajenia i dostosować je do reguł panujących w naszym kraju. Mniej oczywiste niż odpowiedź na to

aspektem napędzającym dążenia „brexitowe” jest obawa przed zbyt gwałtowna globalizacją miejsc atrakcyjnych ekonomicznie i utratą przez nich tożsamości narodowej. Radosław Sikorski mówi: „Nie zauważyłem, żeby przez kilkadziesiąt lat członkostwa w strukturach europejskich Włosi stali się mniej włoscy, Niemcy mniej niemieccy czy Hiszpanie mniej hiszpańscy. Prawda jest, że wiele brytyjskich miast, z Londynem na czele, nabrało o wiele bardziej międzynarodowego charakteru, ale $z$ drugiej strony ta zmiana przyniosła ogromne korzyści gospodarcze. Rozumiem też obawy wynikające z faktu, że niektóre miejsca w Wielkiej Brytanii nabrały innego charakteru kulturowego. Co ciekawe jednak, ten tożsamościowy strach przed zmianą kulturowa jest tym większy, im mniej jest w danym hrabstwie obcokrajowców. To sugeruje, że obcokrajowcy nie są tacy straszni, jeśli tylko się ich pozna" (https://kulturalibe ralna.pl/2016/06/21/radoslaw-sikorski-brexit-wywiad-pawlowski/ [dostęp: 9.04.2019]).

5 Tak społecznych, jak narodowościowych.

${ }^{6}$ Nie są to czynniki jedyne, acz te właśnie z różnych względów wydają się kluczowe dla przebiegu i właściwego poprowadzenia procesu adaptacji.

7 Tu oczywiście znaczący wpływ będzie miała faktyczna sytuacja geopolityczna regionu, z którego dana osoba pochodzi.

8 Jest na to przewidziana przerwa we wszystkich przedsiębiorstwach i na uniwersytetach.

${ }^{9} \mathrm{~W}$ większości przedsiębiorstw i na uniwersytetach nie ma takiej przerwy w ogóle. 
pytanie wydaje się to, co stanowi klucz do przynajmniej częściowego rozwiązania problemu. Aby dokonać jakiejkolwiek adaptacji swojego zachowania do nowych warunków i zmienić przyzwyczajenia, cudzoziemiec musi wiedzieć o obowiązujących w kraju przebywania regułach i normach. We wszechobecnej dyskusji o niechęci migrantów do adaptacji (często zresztą przez obie strony procesu utożsamiane $z$ asymilacja zamiast $z$ integracja, co budzi opór tych, od których zmian się wymaga), przekształcania swoich przyzwyczajeń o aspekcie edukacyjnym jako wspomagającym ów proces wspomina się najrzadziej. Większość ludzi zdaje się zakładać, że migrant wiedzę o nowej kulturze powinien zdobyć z jakiegoś bliżej nieokreślonego źródła i nie widzi konieczności edukowania go w tym zakresie. Chęć zdekodowania zachowań, tradycji czy obyczajów powinna stać się zatem motorem dwukierunkowych wysiłków edukacyjnych - chodzi bowiem nie tylko o motywację do nauki, ale także o to, aby podjąć wysiłek nauczenia kogoś wartości i obowiązujących w danym kręgu kulturowym norm lub przynajmniej objaśnienia istoty wartości i reguł ważnych dla danego kręgu kulturowego i społeczeństwa je akceptującego.

Narzędzia tej edukacji bywają wielorakie. Z perspektywy niniejszych rozważań film jako materiał pomocniczy w procesie adaptacji może odgrywać rolę dwojaka. Po pierwsze, staje się leksykonem umożliwiającym złamanie obcych szyfrów kultury, po drugie zaś, katalizatorem poszukiwań, gdyż współcześnie wydaje się najbardziej rozpowszechnionym i najbardziej (najłatwiej) dostępnym tej kultury nośnikiem ${ }^{10}$.

\section{Proces fosylizacji językowej i kulturowej}

Powszechnie wiadomo, jak ważnym czynnikiem integracji z nowa grupa społeczną, do której trafia jednostka, jest jej język. (...) Istotna rola języka w procesie adaptacji jest często niedostępna potocznej obserwacji

\footnotetext{
10 Uwagi dotyczące doboru materiałów filmowych jako narzędzia pomocniczego w procesie adaptacji migrantów, imigrantów i uchodźców sporządzone zostały na potrzeby tego artykułu z punktu widzenia nauczyciela kultury polskiej i języka polskiego jako obcego. Za przykłady posłużyły zatem przede wszystkim dzieła kinematografii polskiej. Wszystkie zagadnienia, o których mowa w tym tekście, rozpatrywać można jednak na wyższym poziomie uogólnienia. Mogą one zatem dotyczyć sytuacji pozalekcyjnych, jak również mogą odnosić się do wykorzystania dzieł filmowych nie tylko w procesie adaptacji do kultury polskiej.
} 
i wiąże się z rolą języka w uniwersum symbolicznym. Miejsce to jest tak zasadnicze, że niekiedy można powiedzieć, iż język tworzy społeczną rzeczywistość (Niźnik 1985, 74).

Podjęcie wysiłku związanego z nauką języka kraju, w którym rozpoczyna się nowe życie lub podejmuje naukę czy pracę zarobkową, początkowo jest oczywistą koniecznościa. Porozumienie się z pracodawca, współpracownikami, osobami w urzędach, biurach czy bankach, nauczycielami w szkole, do której uczęszczają dzieci, swoimi nauczycielami na uczelni staje się motorem takich działań. Frustracja wynikająca z niemożności porozumienia się motywuje, a właściwie wręcz zmusza do nauki języka, który staje się kluczem do nowej, lepszej przyszłości. Jednak ten początkowy zapał do nauki zostaje w pewnym momencie zahamowany przez kilka czynników. Po pierwsze, możliwość nauki zostaje ograniczona przez rutynę życia codziennego - praca, opieka nad rodziną i inne obowiązki utrudniaja uczestnictwo w regularnych zajęciach, a zmęczenie i nawał obowiązków skutecznie ograniczają chęci samodoskonalenia. Po drugie, mamy do czynienia z sytuacją, w której znajomość języka obcego (często mocno ograniczona) wystarcza do załatwienia najważniejszych spraw i zaspokojenia podstawowych potrzeb. To zjawisko opisywane w opracowaniach glottodydaktycznych, zwane jest fosylizacją:

występuje zwykle wtedy, gdy uczący się przestaje rozwijać swoją kompetencję językową (...) na skutek poczucia (często mylnego), że jest rozumiany przez rodzimych użytkowników danego języka i skutecznie osiąga zamierzone cele komunikacyjne (przykładowo przez regularne używanie rekcji biernikowej zamiast dopełniaczowej w zdaniach typu: W polskim czasu nigdy ona nawet nieumiała język niemiecki; Oni nie umieli serbołużycki). Korzysta z zasobu »skostniałych struktur«, które w języku docelowym moga być poprawne (transfer pozytywny) lub błędne (transfer negatywny). Jak zauważają Selinker i Lamendella, uczeń nie czuje potrzeby dalszej nauki wówczas, gdy jego interjęzyk zawiera przynajmniej kilka reguł różnych od obowiązujących w języku pierwszym (Żurek 2014, 294).

Po trzecie, życie migranta czy uchodźcy często charakteryzuje się zamknięciem na różnorodne bodźce zewnętrzne i zaczyna szybko ograniczać się do pewnych utartych schematów, które powodują zmniejszanie zasobu kompetencji np. leksykalnej. Konieczność (chęć) oszczędzania pieniędzy, ograniczenie grona znajomych wyłącznie do przedstawicieli własnej naro- 
dowości, brak uczestnictwa (z powodów językowych lub finansowych) w życiu kulturalnym i społecznym w nowym kraju powoduja, iż znajomość języka i kultury ${ }^{11}$ osiaga pewną skamieniałą formę i nie jest rozwijana o nowe pojęcia, wyrazy czy formy. ,Jest to zjawisko dość powszechne, a charakteryzuje się tym, że uczący się $\mathrm{J}_{2}$ osiaga pewien poziom jego znajomości - wystarczający, aby funkcjonować w danej społeczności, lecz mimo sprzyjajacych warunków naturalnych nie posuwa się w językowym rozwoju” (Lipińska 2003) ${ }^{12}$.

Jak zatem zmobilizować migranta do podjęcia dalszej edukacji i jak sprawić, aby nabywanie wiedzy nie wiązało się wyłącznie z wysiłkiem i stało się raczej przyjemnością niż źle postrzeganym i męczącym obowiązkiem ${ }^{13}$ ? Pomoca może być film - jako dostępny, tani i łatwo przyswajalny nośnik wiedzy jezzykowej i kulturowej. Zahamowanie procesu rozwoju zasobu leksyki można próbować odwrócić dzięki oglądaniu filmów dotyczących tematów niezwiązanych bezpośrednio z podstawowymi potrzebami życia codziennego cudzoziemca. Filmy, seriale i programy telewizyjne pozwalają rozwijać kompetencję językową i kulturową bez wysiłku, moga być nawet uznane za formę relaksu po trudnym dniu ${ }^{14}$. Ważne jest jednak uwzględnienie kryteriów, jakie powinny być wzięte pod uwage podczas doboru i ewentualnej se-

11 Wychodzę tu z założenia, że znajomość obcej kultury z podobnych powodów podlegać będzie takiemu samemu procesowi fosylizacji jak język.

12 Nieco inaczej ma się sytuacja w przypadku dzieci, uczęszczających do szkół i mających kontakt z rówieśnikami. Por. Hajduk-Gawron 2018a, Hajduk-Gawron 2018b.

13 Wiedza, którą zdobędzie, jest etapem nie tylko rozwoju kompetencji językowej ale także procesu integracji. „Istnieje wiele definicji samego procesu integracji. Integracja dla arabskich respondentów [autor artykułu opisuje politykę integracyjną Polski w kontekście integracji społeczności arabskiej w Polsce - A.T.] to przede wszystkim interakcje z polskim środowiskiem, przyjęcie elementów polskiej kultury, nauka języka oraz poszanowanie miejscowego prawa. Ponadto prawie wszyscy arabscy respondenci stwierdzili, że członkowie diaspory powinni się dostosować do społeczeństwa polskiego i mieć te same obowiązki społeczne. To dostosowanie się do społeczeństwa przyjmującego według części badanych Polaków jest właśnie integracją. Obydwie badane grupy za najlepszy model współistnienia w jednym państwie wybrały integrację z częściowym zachowaniem własnej kultury (równoważność kultur). Część respondentów arabskich stwierdziła również, iż niektórzy członkowie arabskiej diaspory przejęli elementy kultury polskiej: »niektórzy przejęli i doświadczyli tych elementów tak samo jak Polacy, tradycję i zwyczaje - okazje religijne i kulturalne, ubiór, wszystko, zachowują się jak Polacy, odróżnić ich można tylko pod względem koloru skóry (ND29)«, a ich przejęcie uznali za automatyczną integrację" (Switat 2019, 173-174). W zacytowanym fragmencie autor przywołuje wypowiedź jednego z respondentów (oznaczenie: ND29), zachowując jej oryginalną formę językową.

${ }^{14}$ Czyli tak, jak na ogól jest to traktowane. 
lekcji filmów ${ }^{15}$. Będą to przede wszystkim: „wykorzystany w dziele język (m.in. poziom jego wulgarności i zrozumiałość), sposób przedstawiania elementów kulturowych i socjologicznych ${ }^{16}$, kryterium artystyczne oraz różnice kulturowe w obszarach tabuizowanych. Największą i najbardziej problematyczną grupa zagadnień będą zapewne te ostatnie. Do obszarów tabuizowanych w wymiarze globalnym zaliczyć należy: przemoc, wulgarność języka, zjawiska - najogólniej rzecz biorąc - związane z seksualnością człowieka (nagość, erotykę, seks, orientację seksualną oraz przemoc seksualną, czyli gwałt), prywatność i intymność oraz z kolei w wymiarze „lokalnym”, czyli w odniesieniu do konkretnego odbiorcy, kwestie związane z historią. Tabu jest zagadnieniem ściśle związanym z kulturą, w której wyrośliśmy, a także z wychowaniem i innymi czynnikami odrębnymi dla osobowości każdego człowieka" (Tambor 2015, 7).

Propozycje filmów poszerzających wiedzę językową mogą być wielorakie w zależności od celów i oczekiwanych rezultatów. W razie chęci rozwinięcia profesjolektów, np. słownictwa związanego z medycyna, dobrym wyborem może okazać się film Bogowie17; można go śmiało uzupełnić pokazami seriali, które z natury są bardziej przystępne niż film, bo charakteryzują się banalniejszą i łatwiejszą warstwą językowa, nie mają też aspiracji artystycznych, które często utrudniają odbiór niektórych dzieł osobom nieprzygotowanym. Można zatem zaproponować oglądanie Lekarzy, $\mathrm{Na}$ dobre i na złłe, Diagnozyy

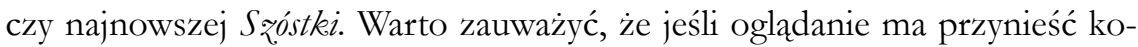
rzyści wyłącznie językowe, nie trzeba ograniczać repertuaru wyłącznie do kina narodowego. Cudzoziemiec wykonujący pracę mechanika samochodo-

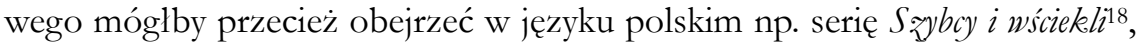
gdyż dla poznawania leksyki tłumaczenia list dialogowych moga być wystar-

15 Zależnie od tego, czy dobór przebiega samodzielnie, czy jest to selekcja prowadzona odgórnie przez nauczyciela, wykładowcę lub lektora.

16 „Filmy, choć odzwierciedlają społeczne i obyczajowe nastroje danego czasu, są także kumulacja pewnych cech czy zachowań i tym samym prezentuja przerysowane obrazy, które mogą urazić lub okazać się »niewychowawcze« w kontekście nauczania języka i obcej kultury. Nauczyciel jpjo musi mieć na uwadze nie tylko możliwie »nagannąu z punktu widzenia dydaktycznego sferę językową bądź kulturową danego filmu, ale przede wszystkim musi wiedzieć, kim są odbiorcy prezentowanych przez niego materiałów. Jeszcze raz zatem podkreślić należy, iż wiek, płeć, a przede wszystkim krąg kulturowy (i status osób), z którego pochodzą studenci, to czynniki, które wpływać muszą na dobór prezentowanych produkcji oraz na cele ich użycia" (Tambor 2015, 85).

17 Reż. Lukasz Palkowski, prod. 2014.

18 Oczywiście rezygnujemy w tym momencie z aspektu edukacji kulturowej. 
czające. Z niektórych ${ }^{19}$ współczesnych komedii romantycznych można z kolei zaczerpnąć leksykę związaną ze światem nowych mediów - Planeta singli20, wiedzę o zwyczajach świątecznych (kolacja wigilijna, kolędy, potrawy) - Listy do $M .^{21}$, wiedzę realioznawczą o różnych grupach społecznych z odpowiednim słownictwem - Plan B22. Z perspektywy edukacyjnej jako źródło wiedzy służyć moga także filmy często pomijane (gdyż niezaliczane do kanonu tzw. polskiego kina artystycznego): takie, jak Cisza (tragiczna historia nastolatków z tyskiego liceum, którzy zginęli w Tatrach) czy Laura ${ }^{23}$ (życie rodziny górnika z ciężką chorobą dziecka jako ważnym tłem). Filmy te proponują ciekawa tematykę (obyczajowo-kulturowa), będąc produkcjami telewizyjnymi o znikomych walorach artystycznych, są jednocześnie bardzo dobrze przyjmowane przez cudzoziemskich widzów. Powody są podobne jak w przypadku wspomnianych wcześniej komedii romantycznych - zrozumiała, uproszczona fabuła i przystępny język. Warto wszak pamiętać w procesie nauczania o tych właśnie tytułach ze względu na ich wartość poznawcza.

Film może stać się też okazją do rozwijania wiedzy i kompetencji językowych w zakresie sposobów spędzania wolnego czasu. Najpopularniejsza dziedziną byłby tu sport. Warto pamiętać, że człowiek zmieniając kraj zamieszkania, nie zawsze chciałby całkowicie rezygnować ze sposobu życia, jaki wiódł wcześniej. Często jednak wstyd - wynikający z braków odpowiedniej wiedzy językowej (nie jest to tematyka poruszana na zajęciach z jpjo) staje się barierą uniemożliwiającą rozwijanie swoich pasjii ${ }^{24}$ I tu film może okazać się pomocny. Wiedzę z zakresu piłki nożnej znajdziemy w takich filmach, jak: Boisko bezdomnych ${ }^{25}$ czy Skrzydlate świnie ${ }^{26}$ (jednocześnie rozbudować można wiedzę o subkulturze hooligans, ta zaś może okazać się, akurat w Polsce, bardzo pomocna w razie zetknięcia się z jej przedstawicielami w prawdziwym życiu) czy Pitkarski poker27 (ułatwi rozmowy i zrozumienie wciąż aktualnych przekazów medialnych dotyczących korupcji

\footnotetext{
${ }^{19}$ Większość komedii romantycznych proponuje oderwany od rzeczywistości obraz wspólczesności.

20 Reż. Mitja Okorn, prod. 2016.

21 Reż. Mitja Okorn, prod. 2011.

22 Reż. Kinga Dębska, prod. 2018.

23 Reż. Radosław Dunaszewski, prod. 2010.

24 Aby pójść na trening (zrozumieć polecenia) czy zapisać się na zajęcia, a nawet kupić czy wypożyczyć sprzęt niezbędny do ćwiczeń trzeba dysponować odpowiednią wiedzą językową.

25 Reż. Kasia Adamik, prod. 2008.

26 Reż. Anna Kazejak, prod. 2010.

${ }^{27}$ Reż. Janusz Zaorski, prod. 1989.
} 
w sporcie), o sportach walki wiele dowiemy się z filmu Underdog 28 (przy okazji widz może poznać jednego z popularniejszych w Polsce sportowców Mameda Chalidowa), o siatkówce zaś traktuje film Druśyna ${ }^{29}$. Zainteresowanie sportami mniej popularnymi pomoże realizować choćby taki tytuł, jak To my, rugbyśs $i^{30}$.

\section{Proces identyfikacji}

W doborze repertuaru dla osób mających zaadaptować się w nowym, obcym środowisku jedną z kluczowych ról odgrywa to, by choć częściowo skupiał się on wokół problemów, z którymi odbiorca filmu może mieć do czynienia. Istotną funkcję w zrozumieniu i odbiorze filmu może zatem spełnić bohater, z którym widz może się zidentyfikować. Identyfikacja przebiega w pierwszym rzędzie na poziomie wieku. Dobrym przykładem może być telewizyjna produkcja Jutro idziemy do kina ${ }^{31}$. Ze względów opisanych wcześniej filmy takie często są pomijane czy wręcz ignorowane, a zamiast nich wybiera się produkcje wysokoartystyczne. W filmie Zaorskiego zaś II wojna światowa ukazana została z perspektywy bardzo młodych ludzi wchodzących właśnie w dorosłość, bohaterowie są tuż po maturze. Jeśli zatem mamy do czynienia z młodzieżą, taki wybór (zaproponować można byłoby także film Jana Komasy Miasto 44) wydaje się korzystniejszy niż wykorzystanie filmu takiego, jak choćby Kanat Andrzeja Wajdy, który narracją estetyką oraz poruszana problematyką nie odpowiada już gustom dzisiejszej młodzieży.

Identyfikacja może przebiegać także na innym niż wiek (i związane $z$ nim porównywalne problemy) poziomie. Niezwykle użyteczne w pracy z obcokrajowcami okazują się filmy, w których mamy do czynienia z bohaterem cudzoziemskim (a tym bardziej właśnie imigrantem lub uchodźca) ${ }^{32}$. Jako

${ }^{28}$ Reż. Mariusz Kuczewski, prod. 2019.

${ }^{29}$ Reż. Michał Bielawski, prod. 2014.

${ }^{30}$ Reż. Sylwester Latkowski, prod. 2000.

31 Reż. Michał Kwieciński, prod. 2017.

32 Np.: Londyńczycy (serial), Szczźśliwego Nowego Jorku (reż. Janusz Zaorski, prod. 1997), Dz̧ikie ró́ze (reż. Anna Jadowska, prod. 2017), Handlarz cudów (reż. Jarosław Szoda, Bolesław Pawica, prod. 2009), Nowy świat (reż. Elżbeta Benkowska, Michał Wawrzecki, Łukasz Ostalski, 2015), Obce niebo (reż. Dariusz Gajewski, prod. 2015), 300 mil do nieba (reż. Maciej Dejczer, prod. 1989), Znam kogoś, keto cię szukea (reż. Julia Kowalski, prod. 2015), Pomiędzy stowami (reż. Urszula Antoniak, prod. 2017). 
ciekawy przykład warto podać tu film Moja krew33, w którym na pierwszy plan wysuwać się będą problemy imigrantki z Wietnamu. Yen Ha pracuje w rodzinnej ,jadłodajni” na Stadionie Dziesięciolecia w Warszawie. Jej drogi krzyżują się z Igorem, szukającym kobiety, która zechce urodzić mu dziecko. Spotkanie dwojga życiowych rozbitków zwraca uwagę widza na przejmująca samotność, z jaką boryka się dziewczyna. Agresja Igora jest przez nią przyjmowana z pewną rezygnacja - brak przyjaznych, bliskich osób i przyjaciół powoduje, że zostaje sama z problemami, z którymi w mniej lub bardziej drastycznej wersji boryka się właściwie każdy cudzoziemiec przenoszący się do odległego kulturowo świata. Praktyka pracy z cudzoziemcami pokazuje, że film bardzo uniwersalnie porusza nuty grające w duszy każdego emigranta ${ }^{34}$.

\section{Proces akomodacji kulturowej czy asymilacji}

Film może służyć jako narzędzie pomocnicze w procesach składających się na właściwą adaptację do nowego środowiska. Należy jednak korzystać z niego rozważnie, aby mógł stać się pomocą w przekształcaniu procesów asymilacyjnych ${ }^{35} \mathrm{w}$ poprawną i konieczną w przypadku zmiany środowiska kulturowego - akomodację. Akomodację chciałabym tu rozumieć jako przystosowanie niezaburzające w sposób destrukcyjny osobowości migranta. Bowiem, jak podkreślaja to badacze procesów interkulturowości, „poprzez intensywny kontakt z obcą kulturą [migrant - A.T.] może doświadczyć zjawiska tzw. szoku kulturowego, który definiowany jest jako: »bardziej lub mnie nagłe, budzące lęk pojawienie się zupełnie odmiennej rzeczywistości właściwej innej kulturze przy bezpośrednim kontakcie z obcą tj. nieuwewnętrznioną kulturąu. To może objawiać się w poczuciu alienacji. A następnie jednostka może przyjąć postawę akulturacji, asymilacji lub integracji, co zależy od pomocy, jaką otrzyma, ale także od takich czynników, jak np. wiek, płeć, stopień otwartości na inne społeczeństwo itp.” (Achtelik, Tambor 2014, 15 za: Kwaśniewski 1982). By osiagnąć efekt adaptacji (integracji), należy dobrać odpowiednie narzędzia owej pomocy. Chcę pokazać właśnie

\footnotetext{
33 Reż. Marcin Wrona, prod. 2009.

${ }^{34}$ Jako wykładowca uniwersytecki byłam świadkiem potoku łez, wywołanego przez film u dwudziestokilkuletniego Gruzina, który nie należał raczej do osób łatwo wzruszających się.

35 „Asymilacja - rezygnacja z własnej tożsamości i przyjęcie nowej kultury” (Hajduk-Gawron 2019, 256).
} 
film jako jedno z najlepszych narzędzi. Narzędzie to musi być jednak wykorzystywane rozważnie i odpowiedzialnie. Ostrożność wynikać powinna z faktu, iź źle dobranym filmem wyrządzić można duże szkody - z nieodpowiednio wyselekcjonowanego materiału wynikać będzie znużenie, zniechęcenie do oglądania innych filmów, zła opinia na temat całego kina narodowego czy wreszcie niechęć do nosicieli kultury reprezentowanej przez obraz filmowy, co po szoku kulturowym może prowadzi do alienacji. Niekorzystna opinia pojawić się może także w razie zmuszania widzów do oglądania filmów mocno niezgodnych z ich własnym kodem kulturowym np. film z dużą ilością scen „rozbieranych” nie będzie nadawał się dla muzułmanów. Takie nietrafne wybory związane bywają najczęściej z brakiem znajomości realiów kraju pochodzenia widzów oraz ze zignorowaniem zakresu obszarów tabuizowanych. Oba te zaniedbania wynikają najczęściej z niewystarczającej wiedzy osoby dobierającej repertuar filmowy lub z przypadkowości wybieranych przez samego widza produkcji. Dla lepszego zobrazowania tych uwag warto przytoczyć kilka przykładów. Studentka z Kazachstanu pytana o to, czy kiedykolwiek tematy uważane przez nią za tabu zostały podjęte podczas zajęć na uniwersytecie, mówi: „Tak, zdarzyło się na lekcji, że profesor poruszył temat obrzezania w niektórych krajach i skomentował, że to absolutne głupstwo. Bardzo nie chciałam o tym rozmawiać, bo w moim kraju jest tak samo". Elementem, który warto byłoby wziać pod uwagę jest zakaz kulturowy - dziś najczęściej religijny. Warto pamiętać, że w niektórych wyznaniach nie zawsze otwarcie można mówić o swoim stanowisku wobec spraw wiary, a także faktach z wiarą bezpośrednio niezwiązanych, a jednak przez nią obwarowanych (np. seks). Współcześnie Polacy dość neutralnie podchodza do tej tematyki, jednak w wielu krajach religia i rozmowy na jej temat, a już w szczególności jej krytykowanie, traktowane jest jako obraźliwe, ubliżające i należy do tematów związanych z tabu. Ankietowani pisza: „Zdarzyło się podczas zajęć, że poruszone były tematy religii. Większość osób negatywnie wypowiada się o muzułmanach, ale wydaje mi się, że problem wynika z niedawnych wydarzeń dotyczących ataków terrorystycznych, ale te opinie są przykre” (Kazachstan), „Nie wypada zapytać o wyznawaną religię i rozmawiać na ten temat”36 (Japonia), „Tematy religijne są omawiane bardzo ostrożnie, nie wolno krytykować prawosławia” (Rosja). Nie jest dobrze odbierane także krytykowanie własnej religii, a dla przedsta-

36 Pytanie o wyznawaną religię pojawia się jednak w Japonii np. w formularzu przyjęcia do lekarza, a w Chinach w formularzach zgłoszeniowych na kursy letnie na wielu uniwersytetach. 
wicieli wielu narodowości - w tym Polaków - niedopuszczalne jest łączenie sfery sacrum z elementami do niej nieprzynależącymi. Ankietowany z Meksyku jako przykład polskiego filmu, który wydał mu się szokujący, podał tytuł Kto nigdy nie $\dot{y} y{ }^{37}$ (historia księdza, który jest nosicielem wirusa HIV), z kolei ankietowany z Rosji w tym samym kontekście przywołał film Małgorzaty Szumowskiej $W$ imie... ${ }^{38}$ (ksiądz-homoseksualista), oburzenie wywołuje tu głównie wulgarność w połączeniu z podmiotami religijnymi.

Religia to wciąż jeden z głównych tematów, jakie wydają się kształtować polski językowy obraz świata i polską rzeczywistość. W Europie i na świecie Polska jest nadal postrzegana jako naród bardzo religijny (katolicki), a uczący się naszego języka cudzoziemcy twierdza, iż ta religijność przejawia się także w podręcznikach. (...) Autorka pracy dotyczącej wartości w podręcznikach do nauki języka polskiego, rumuńskiego i norweskiego mówi: „Polacy są przekonani, że pokazują w podręcznikach obiektywny, neutralny obraz. Cudzoziemcy widzą często nierealny, nierzeczywisty, wyidealizowany obraz rodziny i nadmiar odniesień religijnych" (Tambor 2015, 171 za: Florea-Hygen 2013, 115).

Być może właśnie zatem wykorzystanie filmu związanego z tą materią byłoby dobrym wprowadzeniem do rozmowy na temat pewnych zachowań i elementów polskiej obyczajowości wypływających właśnie z religii katolickiej - kontrowersje pobudzają do dyskusji. Pomocą może tu być np. film Marcina Wrony Chržest, w którym reżyser, poruszając tematykę porachunków gangsterskich, przemyca cały zestaw symboli i nawiązań religijnych. Mamy zatem sam chrzest (w filmie Wrony jest on wykorzystany w różnych kontekstach - sakrament zmazania grzechu pierworodnego, oczyszczenie z win, przyjęcie do nowej grupy, zrobienie czegoś po raz pierwszy), 7 dni (stworzenie świata), wodę, rybę, niebo, odwrócony krucyfiks, Kaina i Abla (film rozpoczyna się ukazaniem ryciny Albrechta Dürera przedstawiającej tych bohaterów biblijnych), chleb, zabójstwo przez uderzenie kamieniem oraz symbole kolorystyczne - przede wszystkim biel (w naszym kręgu kulturowym symbol czystości i niewinności - może stać się pretekstem do rozmowy o symbolice kolorów w różnych kulturach).

Propozycja wykorzystania filmu jako narzędzia pracy glottodydaktyka i konkretne sugestie programowe przedstawione zostały na bazie różnorod-

37 Reż. Andrzej Seweryn, prod. 2006.

38 Reż. Małgorzata Szumowska, prod. 2013. 
nych doświadczeń lektoratowych i wykładowych kontaktów z cudzoziemcami. Byli wśród nich imigranci zarobkowi, reemigranci, uchodźcy, osoby podejmujące naukę języka polskiego - z różnymi życiowymi doświadczeniami, rozmaitymi biografiami, różnorodnymi motywacjami oraz potrzebami językowymi i kulturowymi. Z roku na rok ruchy migracyjne na świecie przybierają na sile, a zatem praca $z$ takimi osobami stanie się już niedługo (o ile nie stała się już) codziennym doświadczeniem każdego nauczyciela, lektora i wykładowcy - nie tylko języka jako obcego, wszak dzieci migrantów bardzo często uczęszczają do szkół funkcjonujących w systemie edukacyjnym kraju osiedlenia. Studenci, uczniowie, ale także osoby, z którymi stykamy się w codziennym życiu, bardzo często oczekują od nas, jako rodzimych nosicieli kultury, wiedzy, pomocy i rady, jak odnaleźć się w obcym dla nich świecie. Warto pamiętać, iż film stać się może doskonałą ilustracją reguł, norm lub zwyczajów, a ich naoczne doświadczenie jest niejednokrotnie o wiele bardziej efektywne niż teoretyczne zapoznanie z nimi poprzez tekst mówiony lub pisany. Film pozwala też na często humorystyczny, ironiczny dystans, który pomaga zrozumieć obraz, a samo słowo bez obrazu - nie zawsze. A dystans wobec siebie, własnych pomyłek wynikających ze zderzenia kultur, niekoniecznie właściwych wyborów językowych i pozajęzykowych zachowań jest człowiekowi w nowym środowisku potrzebny, by uchronić go od negatywnych skutków szoku kulturowego i pomóc w zdrowej integracji z otaczającym światem.

Imigranci w Polsce to przecież część polskiego społeczeństwa. Żyjąc razem na tym samym terenie, obok siebie, należy działać wspólnie - na rzecz dobra kraju, w którym razem się mieszka. Poza tym cudzoziemcy, którzy mieszkają w Polsce, są dla Polaków w pewnym sensie „naszymi” (swoimi) cudzoziemcami. Teraz imigranci, ale z czasem długoterminowi rezydenci, osoby osiedlone bądź nawet obywatele. Imigrant, żeby gdzieś żyć, nie potrzebuje obywatelstwa, ale obywatelstwo wiąże człowieka z miejscem oraz jest konsekwencja jego przywiązania i powiązań z tym krajem (w tym także kulturowych) (Switat 2019, 178-179).

\section{Literatura}

Achtelik A., 2013, Dialog kultur - kultura polska a lokalność, w: Tambor J., Achtelik A., red., Sztuka to rzemiosto. Nauczyć Polski i polskiego, Katowice.

Achtelik A., Tambor J., 2014, Tożsamość - pomiędzy uniwersalnościa europejskościq a polskościq. Przestrzenie negocjacji kulturowych, w: Gajda S., Jokiel I., red., Polonistyka wobec wyzunań wspótczesności, t. 2. 
Florea-Hygen M.C., 2013, Obraz wartości w jezyku polskim (na przyketadzie podręcznikéw do nauczania jezyke polskiego jako obcego) [niepublikowana rozprawa doktorska], Katowice.

Hajduk-Gawron W., 2019, Strategie akulturacyjne a glottodydaktyka, w: Frukacz K., red., Literatura polska w świecie. Recepcja i adaptacja - mecenaty i migracje, Katowice.

Hajduk-Gawron W., 2018a, Uczeń z doświadczeniem migracyjnym w sqkole polskiej i irlandzkiej, „Języki Obce w Szkole", nr 2.

Hajduk-Gawron W., 2018b, Uczniowie cudzoziemsy w polskim systemie edukacyjnym - doświadczenia ślaskich szkót z perspektywy osób prayjmowanych i środowiska prayjmujacego, „Postscriptum Polonistyczne", nr 2.

Kwaśniewski K., 1982, Zderzenie kultur. Tożsamość a aspekty konfliktów i tolerancji, Warszawa.

Lipińska E., 2003, Jezy/k ojczysty, jezylk obcy, jezyle drugi. Wstęp do badań dwujezyczności, Kraków.

Miodunka W.T., Seretny A., red., 2008, W poszukiwaniu nowych rozwiqzań. Dydaktyka jezyka polskiego jako obcego u progu XXI wieku, Kraków.

Niźnik J., 1985, Symbole a adaptacja kulturowa, Warszawa.

Switat M., 2019, Polityka integracyjna Polski a integracja kulturowa spoteczności arabskiej w Polsce, „Postscriptum Polonistyczne”, nr 1.

Tambor A., Tambor J., 2013, Cudzoziemiec w oczach Polaka - odwrotna strona autoportretu. Film jako narzedzie dydaktyczne, w: Glottodydaktyka polonistyczna III., Szczecin.

Zurek A., 2014, Z badań nad interjezykiem, w: Dabrowska A., Dobesz U., red., 40 lat wrockawskiej glottodydaktyki polonistycznej. Teoria i praktyka, Wrocław.

\section{Netografia}

https://www.szkolnictwo.pl/index.php?id=PU7105 [dostęp: 9.04.2019].

Tambor A., 2015, Film jako przedmiot i narzedzie nauczania kultury polskiej i jezylka polskiego jako obcego, w www: https://www.sbc.org.pl/dlibra/show-content/publication/edition/188016? $\mathrm{id}=188016$, (niepublikowana praca doktorska) [dostęp: 10.04.2019].

https:/ / ec.europa.eu/eurostat/statistics-explained/index.php?title=Migration_and_migrant_ population_statistics/pl\#Przep.C5.82ywy_migracyjne:_2_mln_imigrant.C3.B3w_spoza_UE [dostęp: 11.04.2019].

https://pl.wikipedia.org/wiki/Kryzys_migracyjny_w_Europie\#Polska [dostęp: 9.04.2019]. https://kulturaliberalna.pl/2016/06/21/radoslaw-sikorski-brexit-wywiad-pawlowski/ [dostęp: 9.04.2019]. 